\title{
REALIDADE: UMA RAZÃO QUE NÃO SE EXPLICA, MAS SE CRÊ
}

Izabel Cristina de Souza Azzi

Psicóloga; psicanalista; mestre em Psicologia, Universidade RESUMO: A partir do estudo dos textos de Freud e Lacan, procura-se Federal de Minas Gerais (UFMG). demonstrar haver no interior da relação do sujeito com os objetos, constitutivos de sua realidade, um vazio de referência que determina que a realidade psíquica se constitui de uma perda. Para a psicanálise, o acesso à verdade, ou realidade, está ligado à própria divisão do sujeito e ao discurso que o circunda. Pretende-se mostrar que a realidade é uma ordem, ou razão, de estabilidade lógica, à qual o sujeito está assentido, ou seja, crê, sem explicação, e que depende de um princípio de ordenação discursivo, que só pode se exercer se não for questionado pelo sujeito.

Palavras-chave: Realidade psíquica, perda de realidade, referente, assentimento, crença.

ABSTRACT: Reality: a reasoning that cannot be explained, but believed. The author demonstrates, using Freud's and Lacan's theory, the existence of a relation between the subject and the objects, that constitute his reality, an emptiness of references that determines that psychic reality is consisted of a loss. For the psychoanalysis the access to the truth, or reality, is related to subject's division and discourse in which he is embraced. Reality is an order, or reason, of logical stability, to which the subject is assented, he believes, without explanation. The reality depends on arbitrary election of significant as in maître-mot (master word) to constitute one's self, and the principle of discursive ordering, that can only exist if the subject does not question.

Keywords: Psychic reality, loss of the reality, referent, assent, belief.

\footnotetext{
\noção de realidade tem um estatuto curioso na psicanálise, 1 pois significa tanto o campo no qual o sujeito age e sofre a ação, encontrando um limite para seus desejos imperiosos e onipotentes, quanto os meios para, justamente, “realizálos”, isto é, torná-los real. Freud se referia a essa cena como
} 
realidade "exterior", realidade "material”, ou, às vezes, realidade "histórica". A ela se opõe a realidade psíquica, o universo do inconsciente, das fantasias e desejos que cercam e povoam o sujeito, e que são, para ele, tão reais quanto os seus sentidos captam o mundo à sua volta. A realidade psíquica é aquilo sobre o que se trabalha na situação analítica, que, aliás, é um dispositivo calculado para evidenciá-la, exatamente pela exclusão sistemática da realidade exterior.

Neste texto, procuro demonstrar que a constituição da realidade psíquica está ligada à entrada do sujeito na linguagem, à fundação do inconsciente e, conseqüentemente, a uma perda do vínculo com o referente externo. A partir dessa argumentação, pergunto-me se o delírio é generalizável. Descrevo o que Freud delimita como perda da realidade na neurose e na psicose para entender sua especificidade e pensar como é feito o vínculo com a realidade. O ensaio sobre a negação enriquece a discussão sobre as defesas e introduz a noção de discurso, que indica aquilo no qual o sujeito teria de estar assentido, ou seja, crer, para que a realidade e a verdade lhe estejam garantidas. Iniciemos.

Parece haver em muitos textos psicanalíticos uma concepção da realidade externa como sendo algo já dado, algo inquestionável e que serve de referência avaliativa dos processos psíquicos, por exemplo, de processos alucinatórios. Nessa concepção, a realidade externa seria indiscutível e apenas a apreensão que cada um realiza dessa realidade poderia ser questionada. Mas, propomos que há entre elas (realidade psíquica e externa) uma relação estrutural, moebiana, de modo que não podemos separá-las como se separa o joio do trigo. Essa topologia, deduzida a partir de uma análise metapsicológica dos processos e princípios do funcionamento mental, permite uma lógica mais apropriada para a compreensão das relações da neurose e da psicose com a realidade.

Para introduzir o tema, retomo um sonho relatado por Freud (FREUD, 1900/1986). É o sonho de um pai que após a morte do filho, velado num quarto contíguo, sonha que este estava de pé ao lado de sua cama, o apanha pelo braço e lhe murmura: Pai, não vês que estou queimando?

Freud nos conta que, de fato, o velho encarregado de velar o corpo dormira, uma vela tombara e parte do corpo estava em chamas. Mas, o que desperta esse pai? Seu sonho no qual o filho o chama em apelo? Ou o clarão ou algum barulho do quarto ao lado, a realidade mesma de uma vela tombada e que pega fogo na cama onde o filho repousa?

Este sonho nos faz pensar: é verdade que existe uma realidade (dita empírica ou material) que não se pode desconsiderar, pois o corpo do filho está, realmente, começando a queimar na sala ao lado por negligência daquele que deveria vigiá-lo e impedir que a vela caísse. Será esta a realidade que causa o despertar do pai? O que o desperta? Não será, no sonho, uma outra realidade que o desperta? (FREIRE, 1997). 
Os sonhos têm um caráter equivocante para o sujeito justamente porque encenam uma realidade que, por não ser assimilada de forma nenhuma à realidade da vigília, é experimentada como bizarra, estranha. Os absurdos, incoerências, esquecimentos, dúvidas, assim como os lapsos, ganham outra realidade neles, bem como nos sintomas neuróticos. Freud escolhe o sonho para demonstrar a hipótese do inconsciente como uma determinação que exerce seus efeitos sobre o sujeito. O relato do sonho e outros testemunhos de ruptura do sentido permitem recolher o que se inscreve como perda na fala dos analisantes, fazendo com que se confronte com uma realidade outra, diferente da que se articula como sentido na consciência. Dessa forma, o despertar do sonho põe o sujeito diante da contradição no seio da realidade. Como saber se essa situação vivida como realidade é um sonho?

Com Freud aprendemos que todo processo psíquico opera pela heterogeneidade do campo do pensamento que lhe é intrínseca, onde aquilo que confere existência ao representado na consciência já se constitui como um pensamento. Sendo assim, onde está o referente? Se um pensamento é aquilo que se realiza pela representação, o que dá realidade às coisas que se apresentam ao sujeito? Como distinguir, a partir da questão da existência, uma experiência perceptiva de uma alucinatória?

O limite entre a realidade chamada material e a realidade psíquica é tênue. Freud usa dois termos em alemão para nomear a realidade: Realität e Wirklichkeit. Segundo Lacan, no Seminário 7, Freud não os utiliza de forma indiferenciada. Por Realität designa a realidade psíquica que é definida desde o "Projeto" (1895) como a realidade regida pelo princípio de prazer e seu correlato princípio de realidade. Com Wirklichkeit, Freud se refere a uma realidade do externo, do "forarepresentação", realidade que, inicialmente, se apresenta em sua teoria como traumática, mas que pouco a pouco vai sendo assimilada ao funcionamento da estrutura como aquilo que aponta algo da verdade do sujeito e da qual ele não quer saber. A Wirklichkeit é da ordem de uma efetividade muito mais do que uma correspondência com o externo.

Ele parece, inicialmente, sustentar uma distinção entre realidade externa/ material e realidade interna/psíquica e uma busca de compreensão de como a realidade externa se faz interna. No "Projeto", vemos esta distinção que vai se fazendo cada vez menos necessária e aparente. A tese da realidade psíquica como realidade que interessa para a psicanálise superpõe-se de maneira definitiva. Ela demonstra que a relação do sujeito com a realidade já é efeito da forma como esse sujeito se articula no laço social, ou seja, do modo como ele se dirige ao Outro, efeito, portanto, da forma como esta alteridade se apresenta a ele.

Para Freud, toda apreensão humana da realidade está submetida a uma condição primordial — o sujeito está à procura do objeto de seu desejo, mas nada 
pode levá-lo a ele. Assim, a realidade, enquanto sustentada pelo desejo, é, de início, alucinada. Esta condição apresenta-nos uma realidade precária, com a qual o sujeito estará às voltas. A busca do objeto perdido supõe distinções entre realidades, definidas por oposições entre interior/exterior, indiferente/diferente, prazer/desprazer, que se referem à relação do sujeito com o campo do Outro, cujo operador fundamental é a prova de realidade.

Assim, na defasagem entre a percepção evanescente (mas que nem por isso é menos real) e a consciência está o lugar da realidade psíquica (Realität), que nos desperta lentamente para uma outra realidade - a do furo, do barulho, da batida na porta, uma realidade que está ali à espera, e que só se apresenta à consciência a posteriori, sob a forma da representação. Tal realidade, que Lacan localizou como a Wirklichkeit freudiana, é uma realidade fora significante. Este limite à significação só pode ser concebido na fala através da realidade que se rege pelo significante - a realidade psíquica - e por repetições, que são furos na cadeia significante; tal limite é outra realidade, que Lacan denominou 'real'. O encontro com essa realidade ocorre no intervalo ínfimo entre o sonho e o despertar, em outra cena, na qual encontramos também o processo primário, que introduz uma ruptura entre a percepção e a representação consciente; essa realidade - ou real para Lacan — permanece ali retornando na insistência dos signos, nos deslocamentos e condensações, onde se misturam traços do passado e do presente, se repetindo por meio de formas indefinidas da outra realidade, ou da realidade psíquica, que podemos chamar realidades significadas.

O conceito de das Ding, a Coisa, nos ajuda a compreender como a realidade psíquica se constitui a partir da inscrição de uma perda do vínculo com o referente externo, reduzindo-se dessa forma a possibilidade de o simbólico (ou as representações) referir-se à realidade. Há perda. Esta lança o sujeito na errância da linguagem, mas possibilita a construção de uma realidade "psíquica”, ou seja, subjetivada. Das Ding é o termo freudiano para a operação significante acionada na busca do sujeito pelo objeto de uma experiência primordial e mítica de satisfação, que o coloca à deriva das predicações de um objeto, ou de uma constante - a Coisa — instaurada como perda. Situando-se dentro, mas ao mesmo tempo fora, das Ding sustenta uma posição de extimidade - um exterior íntimo ao sujeito. Tal posição é importante para compreendermos a vacilação da consistência da realidade diante do sujeito; se das Ding se propõe a ser algo a se reencontrar, ao mesmo tempo que o sujeito não tem a mínima idéia do que seja, ou melhor, diante de algo que jamais pode conhecer, ele marca a realidade com a possibilidade de perda do que buscamos, mas não reconhecemos, ou com a surpresa de algo que, apesar de novo, desperta a inquietante estranheza. A operação lógica de dedução significante que a formulação de das Ding introduz 
nos ajuda a compreender que a realidade não é, portanto, algo apreensível, mas, certamente, é algo com o qual o sujeito tem de se haver.

No entanto, apesar de a realidade psíquica se constituir a partir da perda do vínculo com o referente externo, questão amplamente debatida por lingüistas, lógicos e filósofos, para a psicanálise importa que a ausência ou a impossibilidade de efetivação das funções nomeadas pelos conceitos de "prova de realidade" e "valor de realidade" implicam em estados considerados patológicos, que se manifestam por alucinação, delírio e experiências de desrealização ou estranhamento (como Freud descreve no texto de 1936 - Um distúrbio de memória na Acrópole). Num texto de 1894, As neuropsicoses de defesa, Freud diz:

“O eu retira-se da representação intolerável (Unerträglich), ${ }^{1}$ mas esta se liga de maneira inseparável a um fragmento da realidade objetiva; e ao mesmo tempo em que o eu realiza essa operação desliga-se também, total ou parcialmente, da realidade objetiva. Esta última é, a meu ver, a condição sob a qual se dá às próprias representações uma vivacidade alucinatória, e assim a partir de uma defesa que teve êxito, a pessoa cai em confusão alucinatória.” (FREUD,1894/1986, p.64-65, grifos nossos)

Neste fragmento, percebemos, entre outras coisas, que para Freud há uma possibilidade de fragmentação da realidade; dividida, podemos nos relacionar com partes dela. Em A interpretação de sonhos demonstra que se pode "brincar com a realidade", tomando partes aqui e acolá dela, para compor um sonho e realizar o desejo, ou seja, construir uma realidade de acordo com os processos imperiosos do Isso, que recebem a regência do Eu e da censura.

Para Freud, os neuróticos não recusam, nem negam, nem fogem da realidade inteira, mas sim de pequenos pedaços dela. A perda da realidade na neurose se dá pela "fuga”, pela evitação, na qual a relação com a realidade aparece de modo conflituoso. Portanto, a ruptura com a realidade na neurose se dá com parte da realidade psíquica, e não com a realidade toda.

No Suplemento metapsicológico à teoria dos sonhos (1917), Freud diz que um pensamento, ao seguir o caminho regressivo, atinge os traços mnêmicos de objetos e encontra a percepção, que é aceita como real; essa "alucinação traz consigo a crença na realidade (Realitätsglaube)" (FREUD, 1917/1986, p.262). Ele já havia dito no Projeto (1895) que a conclusão do ato de pensar leva ao signo de realidade para a percepção, ou juízo de realidade para a percepção, a crença, alcançando-se a meta do trabalho (GABBI JR, 1995, p.46).

\footnotetext{
${ }^{1}$ Unerträglich (intolerável) substituiu Unverträglich (incompatível), que estava na publicação original de 1894. Freud mesmo traduziu a palavra para o francês como inconciliable. O editor acredita que o sentido que Freud queria manter é o de uma representação incompatível, mantendo a idéia de falsas conexões que ele próprio explora neste e em outros artigos.
} 
Então, a realidade além de ser garantida ao sujeito pelo simbólico (representações) e pelo imaginário (imagens, identificações e fantasias), que conformam o campo de sua constituição, ou seja, campo do semblant, precisa ser garantida por um sistema de crença. Voltaremos a este ponto mais adiante, antes gostaria de precisar melhor o que Freud chama de perda da realidade na neurose e na psicose.

Freud diz, no texto de 1924, que o afrouxamento das relações com a realidade é, na neurose, o efeito de um retorno do recalcado para a realidade, sempre conservada, mas, por assim dizer, secundariamente revestida de um "sentido secreto que chamamos de (nem sempre de maneira inteiramente apropriada) simbólico" (FREUD, 1924/1986, p.234). Pensamos que a restrição que faz do termo "simbólico" deve-se ao fato de o Isso não se articular na linguagem comum, que chamamos simbólica, mas se articular de outro modo, alhures, fazendo "símbolos" de qualquer forma. A essência da neurose consiste, portanto, no retorno do recalcado enquanto esse retorno leva à organização da realidade, segundo um sentido "secreto”, “simbólico”. Retorno que não se dá no discurso articulado do sujeito, mas nos sonhos, sintomas, lapsos, atos falhos, esquecimentos, acting-out, em tudo que constitui a trama efetiva da existência. Diante desta, o sujeito encontra-se como que diante de um discurso inscrito em língua estrangeira. ${ }^{2}$

Quando Freud usa o termo "simbólico”, ele parece fazer referência ao desejo, que se revela "estruturado como uma linguagem", antes mesmo que o sujeito compreenda que há discurso. De modo que também na neurose, apesar de o sujeito encontrar-se preso à cadeia da linguagem, algo se destaca dele, provavelmente, esse inarticulável de seu desejo, o que Freud nomeou de recalcamento primário.

Na psicose, há de início um conflito com a realidade exterior, e é aí, a partir desse primeiro tempo, que se produz uma ruptura dos elos com a realidade; daí a necessidade de um segundo tempo, que compense essa perda ou que substitua a realidade perdida por elementos que tomam emprestados do mundo das fantasias, nunca submetidos ao princípio de realidade e únicos materiais nos quais nossos desejos infantis encontram satisfação. Então, na psicose, a perda da realidade ocorre num primeiro tempo, um tempo antes do aparecimento dos delírios, os quais consistiriam no esforço que visa preencher o vazio criado com todos os "materiais" disponíveis do campo das fantasias.

\footnotetext{
2 “Um discurso é aquilo que determina uma forma de liame social” (LACAN, 1985, p.110). Lacan o situa entre a língua - código ou conjunto de convenções adotadas pelo corpo social, que existe, persiste e insiste à revelia do falante - e a fala, que integra o acidental, o episódico, o anedótico e o individual (CABAS, 1982).
} 
A realidade, portanto, não é homônima de realidade exterior, e enquanto o neurótico evita uma relação com a realidade psíquica e rompe com partes desta, emprestando-lhe depois uma significação particular (simbólica, como Freud nomeou), na psicose dá-se esburacamento, dilaceração, hiância na relação com a realidade exterior e, no seu lugar, o sujeito coloca sua própria realidade, fazendo seu remendo.

A negação é uma via que tomaremos para enriquecer esta discussão. Apresentada num texto de 1925, ela é um argumento de Freud, que permite a discussão de duas coisas importantes: primeiro, a possibilidade de inclusão "no dentro" de algo posto "fora”, configurando uma topologia de extimidade para a Coisa, e que permitiu a Freud descrever as operações de afirmação e expulsão (Bejahung e Austossung) compondo os antecedentes necessários para a compreensão das operações de defesa que encontramos na neurose e na psicose. Segundo, a negação importa como operação que permite ao sujeito tirar conseqüências do fato de que foram perdidos os objetos que forneceram a satisfação, ou seja, da perda instaurada por das Ding na entrada do sujeito na linguagem. Assim, a prova de realidade ganha um estatuto mais preciso, na medida que não se trata de uma correção (julgamento) ou controle da realidade psíquica pela material, mas ela se constitui como a própria prova do inconsciente, pois é a operação que revela a ausência da experiência de satisfação e a necessidade de sua presença no campo da representação.

No ensaio sobre a negação, aparece também a importância do discurso: o não, que não há no inconsciente do sujeito, aparecerá na sua fala. Se nomear uma coisa a faz existir, negando-a, pode-se falar dela em situação de exclusão ou de discordância. Freud vê aí o "valor de índice" do momento em que a idéia ou desejo inconsciente irrompe no discurso, tanto na análise como fora dela. Com o não o sujeito profere o que não quer saber. E sua relação com a realidade psíquica se constrói nesse paradoxo.

Para fazer o mundo representado, é necessária a exclusão de uma coisa pressuposta, delimitando um campo entre prazer e realidade, correlativo aos processos primário e secundário, ou ao que Freud chamou identidade de percepção e identidade de pensamento, que delimitamos como campo da realidade. Esta realidade

“...nos arrasta para um lugar bem diferente de algo que possa expressar-se por uma categoria de conjunto - arrasta-nos para um campo preciso, o da realidade psíquica, que se apresenta a nós com o caráter problemático de uma ordem até então jamais igualada." (LACAN, 1959-1960/1988b, p.31-32) 
Este "apelo à ordem”, esta prova de realidade, segundo Lacan, torna indistingüíveis os princípios de prazer e de realidade, pois se faz necessária uma retenção, uma obstrução para que o processo primário passe pelos laços significantes, como modo de cessar a alucinação.

É, pois, sobre a bateria significante incorporada na divisão do sujeito que intervirão as negações do sujeito. E essas permitem a reintrodução do sujeito excluído como falta no campo das representações, como lugar da enunciação, restabelecendo, assim, as representações (Vorstellungen) na sua autenticidade de significantes do Outro. De modo que é o vazio e a perda, introduzidos por essa operação significante, que vêm conferir alguma realidade ao mundo do sujeito. Esta é, entre outras, a especificidade do que a psicanálise propõe às questões relativas à relação entre a linguagem e a realidade.

Assim, se por um lado essa operação nos permite explicar por que alguns sujeitos estão condenados a levar uma existência desprovida da sensação de realidade e outros a uma existência em que a realidade se apresenta por demais animada, por outro lado, esta mesma operação nos coloca a contundente questão do que faz a realidade se contrapor à alucinação se ambas são produtos do mesmo subsolo significante.

Freud diz no Esboço de psicanálise (1938) que o eu, com bastante freqüência, se encontra em posição de desviar alguma exigência que acha aflitiva do mundo externo e isto é feito por meio de uma negação das percepções que trazem ao conhecimento essa exigência oriunda da realidade. Segundo ele, negações desse tipo ocorrem com psicóticos e com fetichistas, mas não apenas com eles, e são consideradas "meias-medidas, tentativas incompletas de desligamento da realidade” (FREUD, 1938/1986, p.233).

A análise dessas negações permite estabelecer as diferenças entre o recalque, a foraclusão e o desmentido. O recalque é uma falha de tradução, um "empurrar para o lado", um deslocamento para outra representação, um falso enlace que permite certo ganho se o sujeito banca seu pré-juízo, sua arbitrariedade; nele, o inconsciente sabe da realidade, a consciência não, ela só conhece elementos desprovidos de sentido.

No desmentido, a representação intolerável é desmentida ao mesmo tempo que subsiste sua aceitação, tendo como conseqüência uma cisão no eu; nele, a realidade é substituída por outra recíproca e este substituto não é uma percepção, mas sim uma crença. Seria, portanto, a negação da crença o que demonstra a importância desta na constituição da realidade.

Na foraclusão, o não-afirmado retornará de fora, do buraco na Realität. Ela é uma operação que intervém no "plano da constituição primitiva do sujeito" (RABINOVITCH, 2001, p.11). Assim, qualquer significante do corpo simbólico primeiro, incorporado pela operação da Bejahung-Ausstossung, pode ser cortado dele 
e lançado nas trevas exteriores: esse foracluído será para sempre "ininscritível, para sempre ilegível, para sempre indizível. Será para sempre excluído da história do sujeito, onde nunca mais será encontrado" (RABINOVITCH, 2001, p.21). Por isso, a foraclusão não define apenas uma operação de defesa do sujeito, localizável no aparelho psíquico. Ela instaura um lugar exterior ao sujeito e distinto daquele do retorno do recalcado: o "fora". Mas nesse caso, ela não seria então generalizável? O que define a foraclusão como mecanismo da psicose?

Jacques-Alain Miller propõe uma foraclusão do sujeito na própria estrutura da linguagem, a partir de um argumento lógico que sustenta que a linguagem é um aparelho fraco para referir a realidade, tese que tenho tentado aqui demonstrar. Assim, a foraclusão do Nome do Pai faz uma restrição à foraclusão (generalizada). O Nome do Pai, como significante privilegiado, produz um efeito de significação, a significação fálica, que atua como uma sinalização do gozo. Em sua falta (ou defeito) aparece um gozo não subjetivado, fora de todo sentido; em outras palavras, um real excluído, uma perda do vínculo com a realidade. Quando esse significante primordial se encontra foracluído, aparece a relação do sujeito com o real. A suplência aqui aparece na forma do delírio. Miller afirma que a construção do delírio se dá, justamente, nesse ponto no qual o vínculo com a realidade fracassa, dizendo:

"Chamo delírio uma montagem de linguagem que não tem correlato de realidade, ou seja, a que nada corresponde na intuição. Chamo delírio uma montagem de linguagem construída sobre um vazio. E digo: todo mundo delira. Essa é a perspectiva que chamo de delírio generalizado." (MILLER, 1999, p.95)

De modo que se estamos todos nesta perda, neste vazio, o que nos impede de ser loucos se o significante como tal nada significa, se a mera consideração da linguagem nos faz supor uma foraclusão generalizável ou uma "clínica universal do delírio"?

Encontramos que Freud também confere à neurose e à psicose uma "etiologia comum”, que seria uma privação (Versagung) da realidade, que, em última análise, é sempre externa. Em suas palavras: "alguma privação desejante da realidade (Wunschversagung)” que lhe parece intolerável (FREUD, 1923-24/1986, p.191). Entendemos que a Ver-sagen (sagen=dizer) configura-se como uma interdição do dizer, imposta pela própria linguagem, uma privação. Isso pode se dar em várias situações e para todos, de modo que ela não é patogênica em si mesma, a possibilidade de adoecer está no modo como o sujeito responde a ela.

O que faz, então, o grampeamento do sujeito à realidade? Se a realidade psíquica se constitui numa relação ao discurso e se não há vínculo entre o discurso e o referente, o que faz com que não vivamos tal discurso como delirante? 
Para tentar responder a estas questões, retomo um artigo de 1936, no qual Freud descreve a Romain Rolland um acontecimento vivido ao visitar a Acrópole, que ele considera marcado pelo que chamou de inquietante estranheza. Tal como Freud, nessa estranha experiência, encontramos na nossa clínica, ou mesmo em nossa vida diária, muitos exemplos desse sentimento de estranheza que nos coloca diante de algo que vivemos em posição de estranha ausência: isso que vejo é real? Ou não?

A vivência na Acrópole configura, na análise que Freud lhe dedica, o estatuto de uma não-crença (Unglaube): "Pelo testemunho de meus sentidos estou agora na Acrópole, mas não posso crê-lo” (FREUD, 1936/1986, p.238). Essa não-crença insere um elemento de dúvida da realidade, que o faz pensar que tudo parte de um fato originário no qual sentiu algo “incrível e irreal”, que compreendia a sua pessoa, a Acrópole e sua percepção da mesma. Esse triângulo nos faz pensar nas coordenadas em que o sentimento de realidade se insere, pois vemos que entre o sujeito que percebe e o percebido, ou seja, o objeto, há a percepção, que parece ser algo que deve ser sustentado por uma crença, caso contrário, produz-se um estranhamento diante desse objeto.

Freud diz:

"Esses estranhamentos são fenômenos muito singulares, pouco compreendidos ainda. Podem ser descritos como 'sensações', mas são, freqüentemente, complicados processos amarrados a certos conteúdos e enlaçados a decisões sobre esses conteúdos. Muito freqüentes em certas doenças psíquicas, tampouco são desconhecidos para o homem normal, assim como as alucinações ocasionais dos sãos. Mas certamente são atos falhos, de estruturas anormais como os sonhos que, apesar de sua aparição regular na pessoa sadia, servem-nos como modelo de perturbação anímica. São observados em duas formas diferentes: ou bem um pedaço da realidade nos parece estranho, ou bem um pedaço do próprio eu." (FREUD, 1936/1986, p.242)

Descreve a experiência realçando a divisão do sujeito e apresenta "a esquize do sujeito entre certeza e dúvida”, e a coexistência da certeza e da dúvida (MILLER, 2005, p.299). Freud compara-a ao sujeito que teria duvidado da existência do monstro de Loch Ness, e que ao vê-lo constata: "Logo, isso existe verdadeiramente?" Esse logo surge não como uma conseqüência lógica, mas como a presença de algo que desmente as considerações anteriores, que é preciso levar em conta, mesmo que se duvide. A partir daí, dessa Verleugnung, desse desmentido da experiência, empreende uma análise da crença e da divisão subjetiva que ela implica. Duvidando de onde chega em sua análise inicial, ou seja, na ênfase posta sobre a autenticidade irremediável do visível, Freud dirige sua atenção à experiência do desejo e à barreira a sua realização, que forneceu a convicção inconsciente presente (tanto nele quanto no irmão) de que afinal seria impossível chegar a Atenas, pois 
isso seria bom demais para ser verdade: Too good to be true. Expressa assim, em língua estrangeira, a experiência de algo irrealizável, como se o sujeito fosse "fundamentalmente cético diante do advento daquilo que lhe traria proveito, do que poderia satisfazê-lo" (MILLER, 2005, p.299). E se pergunta, com a honestidade que lhe é peculiar: "Por que, no entanto, semelhante não-crença frente a algo que, pelo contrário, promete um grande prazer?” (FREUD, 1936/1986, p.239-240).

A descrição desta experiência de estranhamento demonstra um deslocamento do inacreditável: do fato de ver a Acrópole para a existência da mesma, persistindo aí uma recusa em crer, uma descrença. Tal deslocamento repousa sobre a distância entre o significante e a referência e valoriza o poder de irrealização do próprio símbolo, "elidindo a presença do percipiens em prol da dúvida sobre a realidade do perceptum” (MILLER, 2005, p.256). É uma experiência que nos ajuda a sustentar a idéia de que o vínculo com o referente passa necessariamente pela questão da crença, como modo de o sujeito assentir.

O que vejo é real? Como garantir esta certeza? O que me leva a crer no que vejo? E como é feito o vínculo entre a palavra e o referente?

\section{REALIDADE, VERDADE E CRENÇA}

Foucault ajuda a retomar a questão do referente e sua relação com a palavra, tão cara a filósofos e lingüistas. Diz que nem sempre houve uma separação entre as palavras e as coisas, ou nem sempre se pensou nesse encontro como contingente. Localiza esta separação, e mostra como que, a partir disso, cria-se uma nova disposição, na qual a linguagem deixa de ser a escrita material das coisas, passando a ter seu espaço no "regime geral dos signos representativos" (FOUCAULT, 2002, p.59), o que implica o aparecimento de um novo problema, até então desconhecido: Como reconhecer que um signo designe realmente aquilo que significa? Como pode estar ligado àquilo que significa?

Essa questão será respondida, na idade clássica, pela análise da representação e, na idade moderna, pela análise do sentido e da significação. Então, se num primeiro momento só há a representação, num segundo momento esta não representa nada de modo puro (FOUCAULT, 2002). A partir da idade clássica, a linguagem se desenvolve no interior da representação, num desdobramento de si mesma, desenrolando-se nos signos verbais que a manifestam. Torna-se, desse modo, discurso. Substitui-se o enigma de uma palavra que "uma segunda linguagem deve interpretar" (FOUCAULT, 2002, p.109) pela discursividade essencial da representação. Ou seja, não se trata mais de desvelar o "grande propósito enigmático que está oculto sob os signos” do discurso, mas de se perguntar como ele funciona (FOUCAULT, 2002, p.109).

Não cabe mais, portanto, interrogação sobre o valor que tem ou não o signo de representar a realidade. A pergunta que agora parece importar não está mais 
fundada nas questões que a linguagem impõe à relação do homem e seu mundo (interno e/ou externo), mas sim no valor que terá ou não o impulso à verdade, e de onde brota. Uma vez que a ficção, devendo a sua existência inteiramente à linguagem, participa de um modo particular de realidade, aquela verbal, advinda de um radical descolamento da referencialidade imediata, o que importa se o signo toma por referência um outro signo ou objeto? As entidades fictícias, ou seja, fingidas pela imaginação, são, em verdade, fingidas com o propósito de um discurso e não é necessário que tenham substância alguma, pois não se ancoram numa realidade indicada pela percepção, mas, sim, num matiz i-rreal, de uma existência impossível, porém indispensável, ancorado apenas na linguagem. "O fictício, efetivamente, não é por essência o que é enganador, mas, propriamente falando, o que chamamos de simbólico” (LACAN, 1959-60/1988b, p.22).

Quando Freud nomeia como um 'distúrbio de memória' o que lhe ocorreu na Acrópole, aponta o que não funciona, a desarmonia, a dissonância em sua relação com a realidade perceptiva, um vacilar em sua relação com a realidade externa, no qual o tesouro das lembranças encontra-se em perturbação, operando-se um desmentido como defesa. Assim, não há distúrbio na realidade perceptiva, na Wirlichkeit não falta nada, mas é um campo articulado ao desejo e à castração, pois parte de uma falta; daí a necessidade de que a metáfora paterna lhe dê suporte. A crença aponta a posição do sujeito, na medida que expressa aquilo que ele adere. Ela abre, portanto, a dimensão da verdade.

Então, o que torna a verdade efeito de um discurso?

Nietzsche diz que a noção de verdade surge muito depois da criação de um acervo lingüístico geral que sirva às expectativas do grupo, gerado pela dissociação crescente entre as palavras e seu referente. A noção da verdade é a "exigência de que o emprego de um proferimento obedeça àquilo que é costumeiramente admitido como seu sentido” (NIETZSCHE, 2005, p.13). Não havendo referentes dados e admitindo-se que toda regra para o discurso é arbitrária, a verdade passaria a valer tanto quanto qualquer conveniência.

“Que é então a verdade? Um exército móvel de metáforas, de metonímias, de antropomorfismos, numa palavra, uma soma de relações humanas que, foram poética e retoricamente intensificadas, transpostas e adornadas e que depois de um longo uso, parecem a um povo fixas, canônicas e vinculativas: as verdades são ilusões que foram esquecidas enquanto tais. Metáforas que foram gastas e que ficaram esvaziadas de seu sentido, moedas que perderam o seu cunho e que agora são consideradas, não só como moedas, mas como metal.” (NIETZSCHE, 2005, p.13)

Podemos encontrar também nas falas ouvidas na análise este questionamento, o abalo da crença, a disjunção de discursos que fazem referência ao objeto a ser 
conhecido, a incongruência da convenção que estabelece o que ele é. O que nos leva a constatar que o simbólico não descreve a verdade, ou que não há verdade a ser descrita pelo simbólico. A verdade tem estrutura de ficção.

O impulso à verdade requer que a mantenhamos num campo de algo que brota do ficcional, pois apenas deste modo podemos nos aproximar um pouco melhor de seu real. Penso que Lacan introduz o termo semblant para, entre outras coisas, posicionar que não há realidade pré-discursiva: homens, mulheres, crianças são significantes, como diz no Seminário 20. O que vai particularizar o discurso analítico é a idéia de que ao significante daremos uma leitura diferente do que ele significa. Está aí a noção de escuta que deixa ao discurso analítico o potencial de ser "um discurso que não seria do semblant". Como no jogo do semblant de Callois, a dimensão da verdade faz ato, "faz semblant” tal qual a posição do analista, como Lacan vai pensá-la: efeito do semblant.

A Wirklichkeit, portanto, é efeito de discurso, efeito do ato que faz a verdade aparecer. E a crença? Pensemos um pouco a seu respeito, restringindo sua abordagem, no entanto, aos escritos de Freud, quando aborda o tema do assentimento.

Em Moisés e o monoteísmo, pensando sobre a questão da crença num deus único, Freud defende a tese de que é a renúncia pulsional, sob a pressão da autoridade que substitui e prolonga o pai, o que transforma o sagrado em algo que não se pode tocar, proibição cujo tom emocional forte e sem nenhuma base racional só pode ser garantida por um assentimento do sujeito à lei do pai, que é sucedida pela lei sagrada. O que antes era a vontade do pai, passa a ser, a partir do assentimento do sujeito a essa lei, algo que se crê, algo sagrado.

A crença é a atitude de quem conhece como verdadeira uma proposição, portanto, é a adesão à validade de uma noção qualquer, que não implica por si só a validade objetiva da noção à qual adere nem exclui essa validade.

No texto da Acrópole, Freud, ao discutir a descrença, pondera que a idéia que lhe ocorreu, bem como a perturbação da lembrança, se deu em decorrência da seguinte hipótese: "percebe-se precisamente que naquele tempo (do colégio), no inconsciente, não se acreditou nisso; somente agora se adquiria a convicção (Überzeugung) que se estende ao inconsciente” (FREUD, 1936/1986, p.295/296). Mesmo afirmando ser difícil demonstrar essa hipótese, deixa-a no texto marcando uma diferença nos termos que nos leva a pensar que na relação ao inconsciente não se trata apenas do campo da crença. Decanta-se da necessária "construção em análise" não apenas a crença, mas também a convicção na existência do inconsciente. O termo 'convicção' aparece em outros momentos da obra de Freud sempre ligado ao trabalho inconsciente. Numa pesquisa etimológica, ${ }^{3}$ encontramos que 'crença',

\footnotetext{
${ }^{3}$ Dictionnaire dês Racines des Langues Europeennes: Croyance: raiz indo Kret: idée de croyance (religieuse), derivando do latim credere, em croire. Conviction tem como raiz européia weigh; combattre, derivando do latim convincere em convaincre, conviction.
} 
em sua raiz Kret, reporta à idéia de crença religiosa, da fé, enquanto a palavra 'convicção' aponta para 'combater', 'convencer', estando mais ligada ao que se extrai do inconsciente como trabalho, trouvaille, diz Lacan (LACAN, 1971-72) usando uma palavra de sua língua que faz um jogo com a palavra trabalho e a expressão achado no buraco, ou seja, um trabalho que requer a participação do sujeito.

Assim, para defender-se das acusações de que a psicanálise funciona por meio de argumentos apologéticos, uma vez que às proposições do analista tanto faz se o analisante responda sim ou não — o sim é axiomático; o não é resistência —, Freud irá, em Construções em análise, reafirmar os direitos esquecidos do analisante, através da idéia do assentimento (ASSOUN, 1990).

Freud vê na construção do analista um trabalho preliminar, que só irá se completar quando o analisante autenticar a construção, vinculando-a ao seu próprio movimento de rememoração. Portanto, "nada pede ao sujeito verbal do assentimento" (ASSOUN, 1990, p.68) encontra-o no sujeito do inconsciente, mas à revelia de sua própria verbalização. Cabe inteiramente ao analisante tal iniciativa. "Como no caso da negação, existe aí a 'marca de fábrica', que assegura a proveniência inconsciente” (ASSOUN, 1990, p.68).

Lacan diz que o inconsciente é "o capítulo de minha história que é marcado por um branco ou ocupado por uma mentira: é o capítulo censurado. Mas a verdade pode ser reencontrada; na maioria das vezes já está escrita em algum lugar" (LACAN, 1998, p.260). No seminário sobre o saber do psicanalista, ele diz que a palavra define o lugar que se chama a verdade, mas que a verdade não diz toda a verdade, ou ela o diz Autre-ment (avec um grand A), ou seja, o "Outro-mente"; ora, é disso mesmo que trata a psicanálise: de desvelar como se organizam as ficções do desejo do sujeito, numa fabulação suportada somente pela linguagem; ou seja, do lado da verdade do sujeito não há nenhum enraizamento numa referência à realidade como tal, mas somente a dimensão do verossímil, que é uma dizmensão, dit-mansion, pois a verdade reside num meio-dizer, testemunhado desde um lugar Outro. O testemunho de sua veracidade fica fundado no que o Outro se constitui como o lugar que o significante se coloca, naquilo que o inconsciente é o discurso do Outro. A palavra é ela mesma a garantia da autenticidade. A mentira é de estrutura, ou a verdade tem estrutura de ficção. Mas, Lacan marcou isso com o $\mathrm{S}(\mathbb{X})$ : o laço da palavra ao gozo.

Assim, a realidade é abordada com os aparelhos do gozo, aparelho que não há outro senão a linguagem, pois, "no ser falante, o gozo é aparelhado” (LACAN, 1972-73/1985, p.75). O inconsciente insiste, não importa o que se faça, é algo que se repete: instância (insistência) da letra, o inconsciente entrega algo do gozo, mas não tudo. Lacan marca em seu ensino que o discurso analítico situa-se na fronteira entre verdade e saber, mas do saber como fato correlato da ignorância. 
“Isso nos faz ver que, para a psicanálise, a verdade é complexa, desdobrada em ficções e não enunciada de forma simples e direta. Como disse Lacan em seu texto 'A Coisa freudiana', ela exige um percurso, é humilde. Eu acrescentaria que, por característica mesma, ela é soberba, pois é alheia à realidade. Ela é efeito da inadequação entre a palavra. O ato de fala não a diz, a não ser por alusão." (PINTO, 1999, p.72)

Toda essa problemática está ligada ao fato de não haver um referente para o discurso; assim, tanto a verdade por correspondência com a coisa, a verdade da adequação, quanto aquela ancorada na coerência entre os termos da associação livre, são insuficientes para caracterizar as relações entre o significante e o real (nos termos em que a psicanálise trabalha). O discurso se sustenta por meio de um "grampeamento arbitrário efetuado por um elemento do próprio discurso, e que nos dá o semblant de um referente. Isso nos possibilita o laço social e faz com que não vivenciemos o discurso como delirante” (PINTO, 1999, p.72).

Mas como se dá esse grampeamento?

A pesquisa da questão do assentimento nos textos freudianos leva-nos a constatar que este está ligado à questão da autoridade - crer é obedecer; tal autoridade mantém o sujeito enlaçado a um significante ordenador que faz a função da prova de realidade.

Assoun diz que por trás do fato de que um sujeito esteja "propenso" a aceitar um conteúdo explicativo dizendo: “É exatamente isso”, esconde-se a questão da autoridade do analista na transferência (ASSOUN, 1990).

Freud fala sobre isso, no texto Psicologia dos grupos e análise do eu (1921). Quando compara a relação hipnótica ao grupo, diz que desta comparação podemos isolar um elemento relevante ao estudo que é o comportamento do indivíduo em relação ao líder. Chama-lhe a atenção que o assentimento que se faz ao líder, ou ao hipnotizador, mantém o sujeito num estado de "sujeição humilde" e coloca o hipnotizador ou líder no lugar de ideal do eu. Conclui, numa afirmação acrescentada ao texto em 1923:

"O hipnotizador constitui o único objeto e não se presta atenção a mais ninguém que não seja ele. O fato de o eu experimentar, de maneira semelhante à do sonho, tudo o que o hipnotizador possa pedir ou afirmar, relembra-nos que nos esquecemos de mencionar entre as funções do ideal do eu a tarefa de verificar a realidade das coisas. Não admira que o eu tome uma percepção por real, se a realidade dela é corroborada pela instância mental que ordinariamente desempenha o dever de testar a realidade das coisas." (FREUD, 1921/1986, p.145)

Ou seja, além do gesto normativo que institui a realidade como uma ordem à qual o sujeito está ligado por estar na linguagem, há a questão do assentimento, e, por trás desta, a questão da autoridade fazendo a função de teste de realidade. 
Esta questão é relevante quando pensamos a clínica psicanalítica como uma clínica sob transferência. Se a realidade não se constitui como algo que tem existência ontológica comum a todos os indivíduos pertencentes a um grupo, mas, ao contrário, vem atingir o sujeito no ponto mesmo em que uma determinação ligada a ele emerge como verdade, ela só será reconhecida como sua realidade, sustentáculo de sua fantasia, se ele estiver assentido nessa determinação que exerce sobre ele um poder.

Trabalhando essa questão em outras referências, podemos dizer que o significante só poderá “fazer sociedade de significantes” (LACAN, 1970-71, p.14) por intermédio da eleição arbitrária de um significante qualquer como maître-mot (Palavra-Amo ou Palavra-mestre) que faz a função do laço (MILNER, 1999).

Milner sustenta o uso de uma topologia borromeana para pensar o enlaçamento dos três registros ( $R$, S e I) na análise da questão do vínculo com a realidade e a função desse significante qualquer como Palavra-Amo. Para ele, a realidade torna-se nossa Palabra-Amo: nome que está enlaçado (no nó Borromeu), dando corpo a nossas crenças infatigáveis. Essas crenças são, em suas palavras: "a sistemática sinonímia dos Uns e a possibilidade última de dominar os homônimos"4 (MILNER, 1999, p.72). A realidade torna-se referência, quando separada de toda a palavra, mas, por outro lado, em conseqüência da sinonímia, ela é sempre dizível. O enodamento permite formas de encontro contingente, que toca o Um de cada registro ( $R, S$ e I), conseguindo, assim, uma nomeação real, um nome que é o resumo de toda sinonímia contingente do Um. Na clínica, chamamos esse representável contingente de caso, um nome próprio ou o real de uma posição subjetiva, singular. Chamamos a esse encontro de sentido, quando o efeito de verdade de um proferimento se separa de suas significações representáveis e excede seu material significante. Por fim, chamaremos verdade a algo que aponte para o efeito (o efetivo) resultante de um enunciado, no momento desse ato (MILNER, 1999). Por isso, podemos dizer que o verdadeiro, a realidade e o semblant são da mesma ordem (MILLER, 1992). Essa ordem é a do nó (Borromeu), que enoda os três registros ( $R, S$ e I).

Concluindo, o sujeito lida com uma realidade precária por estar na linguagem. Por sua vez, o discurso (a partir do qual se conecta ao referente) só permite referir a linguagem à realidade ao colocá-la sob o registro do significante mestre ou Palavra-Amo. A realidade depende, para se constituir, da eleição arbitrária de

\footnotetext{
${ }^{4}$ Milner, J.-C. (1999) Homonímia: freqüência ou ocorrência de nomes iguais. Sinonímia: freqüência ou ocorrência de palavras com o mesmo sentido. Tradução feita por mim, do texto em espanhol.
} 
um significante qualquer como Palavra-Amo, cuja consistência lógica apóia-se, em última instância, sobre a base ilógica do assentimento, que é uma crença, uma apreensão, um ato, que exige do sujeito a adesão a uma norma que não demonstra sua razão de ser. No entanto, esse ponto encerra a possibilidade de dispersão radical da realidade, mas não depende de um cálculo subjetivo. A ordenação do referente pela Palavra-Amo, deriva, portanto, de um princípio que só pode se exercer se não for questionado pelo sujeito.

Trata-se de um princípio que deve ter inquestionavelmente razão, por ser a própria possibilidade de julgamento factual sobre verdade e erro, o que torna a realidade uma razão que não se explica.

O psicótico contesta esse princípio de ordenação discursiva do significante que não se explica. A perda da realidade resultaria de sua recusa em aceitar a coesão arbitrária da realidade imposta pela Palavra-Amo. A foraclusão incide não propriamente sobre o significante, mas sobre a função de comando que lhe deveria ser atribuída.

Segundo Milner, a Palavra-Amo autoriza todo enunciado que se profere, e se todas são desvalorizadas nenhum enunciado será válido; esse desprezo se estenderá dos conjuntos dizíveis a tudo o que se diz, ao fato mesmo de que se diga. Na esquizofrenia há a "língua de órgão"; o órgão não se separa da palavra, coisa e palavra se confundem. O Outro não se separa de das Ding, o olho se olha, a boca se come, a voz se fala, a pulsão não passa pelo Outro. "O buraco é um buraco" (FREUD, 1917-1915/1986).

Assim, se pensamos a realidade como efeito do real, ela seria uma "ordem" (e aí exploramos o termo como Lacan nos dá) de estabilidade lógica, e acreditamos que também topológica, que liga elementos e leva ao efeito necessário de ordenamento do mundo em um sistema regular. Tal sistema possui, portanto, uma consistência lógica e prescreve um sentido — o que chamamos 'discurso'.

O termo 'realidade' assina o que chamamos uma coisa, seus traços, seu lugar e seu nome; não sem, contudo, reivindicar seu estatuto de real. 


\section{REFERÊNCIĀS}

ASSOUN, P.-L. (1990) Freud e Wittgenstein. Rio de Janeiro: Campus. (1996) Metapsicologia freudiana, uma introdução. Rio de Janeiro:

Jorge Zahar.

CABAS, A. G. (1982) Curso e discurso da obra de Jacques Lacan. Biblioteca Freudiana Brasileira. São Paulo: Moraes.

DICTIONNAIRE DES RACINES DES LANGUES EUROPEENNES (1948). Libraire Larousse: Paris.

DUCROT, O. (1984) Referente, in Enciclopédia Einaudi. Linguagem-Enunciação. Portugal: Imprensa Nacional Casa da Moeda, v.2.

FOUCAULT, M. (2002) As palavras e as coisas. São Paulo: Martins Fontes. FREIRE, A. B. (1997) Por que os planetas não falam? O real na psicanálise e na ciência moderna. Rio de Janeiro: Revinter.

FREUD, S. (1986) Edição standard brasileira das obras psicológicas completas de Sigmund Freud. Rio de Janeiro: Imago.

(1894) “As neuropsicoses de defesa”, v.III, p.57-75.

(1895) "Projeto para uma psicologia científica", v.I, p.381-511.

(1900) “A interpretação de sonhos”, v.IV- V, p.1-752.

[1917(1915)] "Suplemento metapsicológico à teoria dos sonhos", v.XIV, p.253-275.

(1921) "Psicologia de grupo e a análise do eu”, v. XVIII, p.91-184.

[1924(1923)] “Neurose e psicose”, v.XIX, p.189-199.

(1924) “A perda da realidade na neurose e na psicose”, v.XIX, p.229239.

(1925) “A negação”, v.XIX, p.295-309.

(1936) “Um distúrbio de memória na Acrópole”, v.XXII, p.293-307.

(1937) “Construções em análise”, v.XXIII, p.291-309.

[1939(1934-1938)] “Moisés e o monoteísmo”, v.XXIII p.1-168.

(1940 [1938]) “Esboço de psicanálise”, v.XXIII, p.168-247.

. (2004) Escritos sobre a psicologia do inconsciente. Tradução Luiz Alberto

Hanns. Rio de Janeiro: Imago.

(1911) “Formulações sobre os dois princípios do acontecer psíquico", v.I.

GABBI JR. O. F. (1895/1995) Projeto de uma psicologia. Rio de Janeiro: Imago.

LACAN, J. (1955-1956/1988a) O seminário livro 3, As psicoses. Rio de Janeiro: Jorge Zahar.

. (1959-1960/1988b) O seminário livro 7, A ética da psicanálise. Rio de Janeiro: Jorge Zahar.

(1964/ 1988c) O seminário livro11, Os quatro conceitos fundamentais da psicanálise. Rio de Janeiro: Jorge Zahar.

(1970/71) O seminário livro 18, D’un discours qui ne serait pas du sem-

blant. Publicação e tradução para uso interno do Centro de Estudos Freudianos de Recife (Inédito).

(1971/72) O seminário, O saber do psicanalista. Publicação e tradução por Luiz de Souza Dantas Forbes, para uso interno da Biblioteca Freudiana Brasileira (Inédito). 
(1972-73/1985) O seminário, livro 20: Mais, ainda. Rio de Janeiro: Jorge Zahar.

. (1998) "Função e campo da fala e da linguagem em psicanálise”, in Escritos. Rio de Janeiro: Jorge Zahar.

MILLER, J-A. (1999) A psicose no texto de Lacan. Curinga, n.13. Belo Horizonte: EBP/MG, p.92-101

(2005) Silet - Os paradoxos da pulsão, de Freud a Lacan. Rio de Janeiro: Jorge Zahar.

MILNER, J.-C. (1999) Los nombres indistintos. Buenos Aires: Manantial.

NIETZSCHE, F. W. (2005) Acerca da verdade e da mentira; O anticristo. Tradução de Heloisa da Graça Burati. São Paulo: Rideel. Biblioteca Clássica.

PINTO, J. M. (1998/99) Verdade e ficção em uma erótica pragmática. Aletria: revista de estudos de literatura, v.6. Belo Horizonte: Pos-Lit, Faculdade de Letras da UFMG, p.69-76.

VIDAL, E. (1988) Comentários sobre Die Verneinung. Revista Letra Freudiana: Die Verneinung (A negação), ano VII, n.5. Rio de Janeiro, p.8-122.

(1989) Um encontro singular com a Acrópole. Revista Letra Freudiana, ano VIII, n.6. Rio de Janeiro, p.5-115.

Izabel Cristina de Souza Azzi

bel.azzi@gmail.com 